\title{
Genetic Polymorphisms Associated with impaired Folate Cycle and the Risk of Thrombophilia in Pailients with Retrochorial Hematoma in the First Trimester of Pregnancy
}

DOI: $10.17691 / \mathrm{stm} 2015.7 .3 .12$

Received September 25, 2014

1.0. Bushtireva, MD, DSC, Professor, Head of the Department of Obstetrics, Gynecology and Perinatology';

N.B. Kuznetsova, MD, PhD, Associate Professor, Department of Obstetrics, Gynecology and Perinatology'; E.I. Pelogeina, Obstetrician-Gynecologist ${ }^{2}$

'Rostor State Medical University, 29 Nahichevansky Per., Rostov on Don, 344022, Russian Federation;

2Perinatal Center, 90 Bodraya St., Rostov-on-Don, 344068, Russian Federation

The aim of the investigation is to evaluate the role of polymorphisms of folate cycle and hemostatic system in the genesis of chorion detachment

Materials and Methods. The study involved 43 pregnant women with a detachment of the chorion (group 1) and 43 pregnant women without it (group 2, control group). All patients underwent genotyping of 4 gene polymorphisms of folate cycle in the first trimester: MTHFR

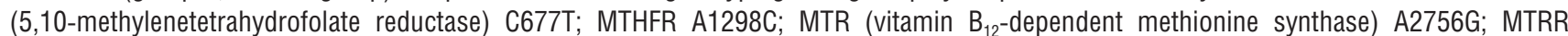
(methionine synthase reductase) A66G and 8 gene polymorphisms of the hemostatic system: F2 (prothrombin, FII) G20210A; F5 (proaccelerin, labile factor, FV) G1691A (Leiden mutation); F7 (proconvertin, FVII) G10976A; F13 (fibrinase, FXIII) G>T; FGB (fibrinogen $\beta$-chain) G455A; ITGA2 ( $\alpha$-2-integrin) C807T; ITGB3 (platelet glycoprotein IIla) T1565C; PAl-1 (plasminogen activator inhibitor 1) -675 5G/4G.

Results. Heterozygous variant GA of F7 (proconvertin, FVII) G10976A polymprphism and mutant homozygote GG variant of MTRR A66G polymorphism were statistically significant for the risk of chorion detachment. The frequency of heterozygous variant $G A$ of $F 7353 G \mid n$ (G10976A) gene polymorphism in patients with chorion detachment was $51 \%$ (22 women) compared to $23.2 \%$ (10 women) in the control group, homozygous variant GG of MTRR A66G polymorphism amounted to $44 \%$ (19 women) relative to $25.6 \%$ ( 11 women) in the control group.

Conclusion. On the basis of the study it can be concluded that chorion detachment in women being in the first trimester of pregnancy may be associated with the availability of heterozygous variant of (proconvertin, FVII) G10976A polymorphism of gene F7 and mutant homozygous GG variant of MTRR A66G polymorphism, that can occur both separately and in combination.

Key words: chorion detachment; thrombophilia; gene polymorphism; proconvertin.

Chorion detachment is a common complication of pregnancy and according to various authors occurs in $3-18 \%$ of cases $[1,2]$. In $50 \%$ of pregnant women retrochorial hematoma results in miscarriage [3]. In the other half it increases the risk of maternal and neonatal complications: gestation hypertension, preeclampsia, placental abruption, retardation of fetal growth, fetal distress, etc. [4].

A new insight into the pathogenesis of chorion detachment and premature abruption of the normally located placenta became possible thanks to the discovery of genetic and acquired thrombophilia, the terms that were introduced into clinical practice to determine the conditions of increased risk of thrombosis and thromboembolism $[5,6]$.

In numerous cohort and population studies association between chorion detachment and thrombophilia has been frequently discussed. Gene polymorphism, involved in coagulation and fibrinolysis, gained the greatest interest
[7-12]. The role of gene polymorphism of folate cycle in the development of early thrombophilic complications in pregnancy has been also considered [13,14]. Sometimes these investigations are rather controversial, underlining the interest to the problem.

Since studying the medical aspects of genetic polymorphism composes conceptual and methodological basis of predictive medicine [15], extensive and deep knowledge on prevention of one of the earliest and commonest pregnancy complications, i.e. chorion detachment and late gestation complications (preeclampsia, placenta abruption, fetal growth retardation) pathogenetically associated with it, is vital in modern obstetrics [16, 17].

The aim of the investigation is to evaluate the role of polymorphisms of folate cycle and hemostatic system in the genesis of chorion detachment.

Materials and Methods. The investigation was carried out in the Perinatal Center (Rostov-on-Don, Russia) 
in 2013-2014. Group 1, the main group, included 43 women with chorion detachment in the first trimester of pregnancy, verified by ultrasound examination at $6.8 \pm 1.3$ weeks' gestation time. 43 patients with a normal course of pregnancy composed control group 2. The average age was $30.0 \pm 0.8$ and $29.0 \pm 0.9$ years.

Pregnancy resulting from assisted reproductive technologies was excluded from the study.

The study complies with the Declaration of Helsinki (the Declaration was passed in Helsinki, Finland, June, 1964, and revised in October, 2000, Edinburg, Scotland) and was performed following approval by the Ethic Committee of Rostov State Medical University. Written informed consent was obtained from every patient.

All patients underwent standard clinical laboratory investigations, including general clinical tests, hemostasiologic and ultrasound examination.

Folate Metabolism SNP Genotyping Kit (DNATechnology, Russia) was used to determine genetic polymorphisms, associated with folate cycle disorder. Trombophilic Risk SNP Genotyping Kit (DNATechnology, Russia) was used to determine genetic polymorphisms, associated with the risk of thrombophilia development.

All patients underwent genotyping of 4 gene polymorphisms of folate cycle in the first trimester: MTHFR (5,10-methylenetetrahydrofolate reductase) C677T; MTHFR A1298C; MTR (vitamin $\mathrm{B}_{12}$-dependent methionine synthase) A2756G; MTRR (methionine synthase reductase) A66G and 8 gene polymorphisms of the hemostatic system: F2 (prothrombin, FII) G20210A; F5 (proaccelerin, labile factor, FV) G1691A (Leiden mutation); F7 (proconvertin, FVII) G10976A; F13 (fibrinase, FXIII) G>T; FGB (fibrinogen $\beta$-chain) G455A; ITGA2 ( $\alpha$-2-integrin) C807T; ITGB3 (platelet glycoprotein Illa) T1565C; PAl-1 (plasminogen activator inhibitor 1) -675 5G/4G.

Hemostasiologic tests included determination of activated partial thromboplastin time, prothrombin index, thrombin time, fibrinogen level, antithrombin III level, D-dimer, soluble complexes of fibrin monomers.

Ultrasound examination was performed using Philips HD 11 device (Philips, Holland). Special attention was paid to retrochorial hematoma, its size and localization.

It was found from the past histories, that 22 women $(51 \%)$ had intrauterine interventions, of them spontaneous abortions were in 5 women, non-developing pregnancy in 10, artificial abortion in 7 , which might lead to chronic endometritis, implantation impairment, and due to inadequate penetration of chorion villi, to the detachment during the course of pregnancy. Intrauterine interventions in group 2 were noted to occur only in 12 cases $(27.9 \%)$.

Infertility in the history was in 6 patients of group 1, in 5 women in group 2; congenital uterus malformation (uterus bicornis, uterus arcuatus) in 2 patients in group 1 , and in 1 woman in group 2; hysteromyoma in 5 patients in group 1, and in 4 in group 2.

Patients in both groups had similar somatic status: chronic pyelonephritis, chronic gastritis, chronic pancreatitis, vegetative-vascular dystonia, chronic tonsillitis are equally noted in the investigated groups.

Statistical data processing was performed by means of tests for Hardy-Weinberg equilibrium, associations were revealed by $\chi^{2}$ method using DeFinetti program. All statistical calculations were considered significant at $p<0.05$.

Results and Discussion. The analysis of gene polymorphisms associated with the risk of thrombophilia development and folate cycle enabled us to assess the frequency of alleles, genotypes of polymorphic loci of the investigated genes in pregnant women in the first trimester and define their association with chorion detachment (See the Table).

Statistical data processing by means of HardyWeinberg equilibrium tests and revealing associations by $\chi^{2}$ method demonstrated statistical significance of frequency of heterozygous variant of F7 (proconvertin,

Frequency of alleles, genotypes of polymorphic loci of the investigated genes in pregnant women in the first trimester and their association with chorion detachment (abs. number/\%)

\begin{tabular}{|c|c|c|c|c|c|}
\hline $\begin{array}{l}\text { Chorion condition } \\
\text { in the group } \\
\text { of pregnant women }\end{array}$ & \multicolumn{3}{|c|}{ Genotype frequency } & $\begin{array}{c}\text { Compliance with } \\
\text { Hardy-Weinberg law } \\
\left(\chi^{2} \mathrm{df}=1\right)^{*}, \mathrm{p}\end{array}$ & $\begin{array}{l}\text { Revealed association } \\
\text { (odds ratio - OR) }\end{array}$ \\
\hline \multicolumn{6}{|c|}{ MTHFR (5,10-methylenetetrahydrofolate reductase) C677T } \\
\hline & CC & CT & TT & & \\
\hline With detachment & $23 / 53.5$ & $15 / 34.9$ & $5 / 11.6$ & $p=0.3122$ & \multirow{2}{*}{$\begin{array}{l}\text { For allele } T: O R=183 \text {, } \\
p=0.7430\end{array}$} \\
\hline Without detachment & $23 / 53.5$ & $17 / 39.5$ & $3 / 7$ & $p=0.9530$ & \\
\hline \multicolumn{6}{|c|}{ MTHFR (5,10-methylenetetrahydrofolate reductase) A1298C } \\
\hline & AA & $\mathrm{AC}$ & CC & & \\
\hline With detachment & $20 / 46.5$ & $16 / 37.2$ & $7 / 16.3$ & $p=0.2353$ & \multirow{2}{*}{$\begin{array}{l}\text { For allele } C: 0 R=1.178 \\
p=0.6481\end{array}$} \\
\hline Without detachment & $21 / 48.8$ & $17 / 39.5$ & $5 / 11.6$ & $p=0.5897$ & \\
\hline
\end{tabular}




\section{End of the Table}

\begin{tabular}{|c|c|c|c|c|c|}
\hline $\begin{array}{l}\text { Chorion condition } \\
\text { in the group } \\
\text { of pregnant women }\end{array}$ & \multicolumn{3}{|c|}{ Genotype frequency } & $\begin{array}{l}\text { Compliance with } \\
\text { Hardy-Weinberg law } \\
\qquad\left(\chi^{2} \mathrm{df}=1\right)^{*}, p\end{array}$ & $\begin{array}{l}\text { Revealed association } \\
\text { (odds ratio - OR) }\end{array}$ \\
\hline \multicolumn{6}{|c|}{ MTR (vitamin $B_{12}$-dependent methionine synthase) A2756G } \\
\hline & $\mathrm{AA}$ & $A G$ & GG & & \\
\hline With detachment & $24 / 55.8$ & $17 / 39.5$ & $22 / 4.6$ & $p=0.6412$ & \multirow{2}{*}{$\begin{array}{l}\text { For allele G: } 0 R=0.903 \text {, } \\
p=0.8585\end{array}$} \\
\hline Without detachment & $24 / 55.8$ & $16 / 37.2$ & $3 / 7$ & $p=0.8815$ & \\
\hline \multicolumn{6}{|c|}{ MTRR (methionine synthase reductase) A66G } \\
\hline & $\mathrm{AA}$ & $A G$ & GG & & \\
\hline With detachment & $3 / 7$ & $21 / 48.8$ & $19 / 44.2$ & $p=0.3805$ & \multirow{2}{*}{$\begin{array}{l}\text { For allele G: } O R=2.503 \text {, } \\
p=0.0090\end{array}$} \\
\hline Without detachment & $12 / 27.9$ & $20 / 46.5$ & $11 / 25.6$ & $p=0.6496$ & \\
\hline \multicolumn{6}{|c|}{ F2 (prothrombin, FII) G20210A } \\
\hline & $G G$ & $\mathrm{GA}$ & $\mathrm{AA}$ & & \\
\hline With detachment & $40 / 93$ & $1 / 2.3$ & 2/4.6 & $p=0.7364$ & \multirow{2}{*}{$\begin{array}{l}\text { For allele } A: 0 R=0.833, \\
p=0.8212\end{array}$} \\
\hline Without detachment & $40 / 93$ & 0 & $3 / 7$ & $p=0.6868$ & \\
\hline \multicolumn{6}{|c|}{ F5 (proaccelerin, labile factor, FV) G1691A (Leiden mutation) } \\
\hline & GG & GA & $\mathrm{AA}$ & & \\
\hline With detachment & $36 / 83.7$ & $6 / 13.9$ & $1 / 2.3$ & $p=0.2564$ & \multirow{2}{*}{$\begin{array}{l}\text { For allele } A: 0 R=1.683 \\
p=0.1750\end{array}$} \\
\hline Without detachment & $41 / 95.3$ & $1 / 2.3$ & $1 / 2.3$ & $p=0.0000$ & \\
\hline \multicolumn{6}{|c|}{ F13 (fibrinase, FXIII) G>T } \\
\hline & GG & GT & TT & & \\
\hline With detachment & $20 / 46.5$ & $22 / 51.2$ & $1 / 2.3$ & $p=0.0750$ & \multirow{2}{*}{$\begin{array}{l}\text { For allele } T: 0 R=1.808 \\
p=0.4091\end{array}$} \\
\hline Without detachment & $23 / 53.5$ & $20 / 46.5$ & 0 & $p=0.0469$ & \\
\hline \multicolumn{6}{|c|}{ F7 (proconvertin, FVII) G10976A } \\
\hline & $\mathrm{GG}$ & $\mathrm{GA}$ & $\mathrm{AA}$ & & \\
\hline With detachment & $17 / 39.5$ & $22 / 51.2$ & $4 / 9.3$ & $p=0.4079$ & \multirow{2}{*}{$\begin{array}{l}\text { For allele } A: 0 R=3.131 \\
p=0.0013\end{array}$} \\
\hline Without detachment & $32 / 74.4$ & $10 / 23.2$ & $1 / 2.3$ & $p=0.8361$ & \\
\hline \multicolumn{6}{|c|}{ ITGA2 ( $\alpha 2$-integrin) C807T } \\
\hline & $\mathrm{CC}$ & CT & TT & & \\
\hline With detachment & $15 / 34.9$ & $20 / 46.5$ & $8 / 18.6$ & $p=0.7707$ & \multirow{2}{*}{$\begin{array}{l}\text { For allele } T: \text { OR=0.878, } \\
p=0.6418\end{array}$} \\
\hline Without detachment & $12 / 37.9$ & $23 / 53.5$ & $8 / 18.6$ & $p=0.6039$ & \\
\hline \multicolumn{6}{|c|}{ ITGB3 (platelet glycoprotein IIla) T1565C } \\
\hline & TT & $\mathrm{TC}$ & $\mathrm{CC}$ & & \\
\hline With detachment & $31 / 72$ & $11 / 25.6$ & $1 / 2.3$ & $p=0.9834$ & \multirow{2}{*}{$\begin{array}{l}\text { For allele } \mathrm{C}: \mathrm{OR}=1.268 \\
\mathrm{p}=0.5111\end{array}$} \\
\hline Without detachment & $34 / 79$ & $8 / 18.6$ & $1 / 2.3$ & $p=0.5344$ & \\
\hline \multicolumn{6}{|c|}{ PAI-1 (plasminogen activator inhibitor 1) -675 5G/4G } \\
\hline & $5 \mathrm{G} / 5 \mathrm{G}$ & $4 \mathrm{G} / 5 \mathrm{G}$ & $4 G / 4 G$ & & \\
\hline With detachment & $9 / 20.9$ & $21 / 48.8$ & $13 / 30.2$ & $p=0.9230$ & \multirow{2}{*}{$\begin{array}{l}\text { For allele } 4 \mathrm{G}: 0 R=1.841 \text {, } \\
p=0.0620\end{array}$} \\
\hline Without detachment & $4 / 9.3$ & $19 / 44.2$ & $20 / 46.5$ & $p=0.8659$ & \\
\hline
\end{tabular}

* Criterion $\chi^{2}$ was used to assess the compliance of the observed (sampling) genotype distribution with the expected (population) one at Hardy-Weinberg equilibrium in all groups for all investigated gene polymorphisms, i.e. frequency of gene polymorphism in the sample corresponds to the distribution of genes in a population.

FVII) G10976A gene polymorphism and mutant polymorphism in pregnant women with chorion homozygote GG variant of MTRR A66G gene detachment. Frequency of heterozygous variant GA 
of F7 353Gln (G10976A) polymorphism in our patients amounted to $51 \%$ (22 women), and that of homozygote variant GG of MTRR A66G 44\% polymorphism (19 women). Notably, that in our study there was not established any relation between chorion detachment and presence of low-functional alleles of genotype MTHFR 667T in the examined women.

The study also showed, that in the carriers of allele G10976A of gene F7 the risk of retrochorial hematoma was 3.1 times higher $(\mathrm{OR}=3.131 ; \mathrm{p}=0.00134)$, and it was 2.5 times higher in case of mutant homozygote variant of gene MTRR A66G relative to the similar risk in pregnant women without chorion detachment $(\mathrm{OR}=2.503$; $\mathrm{p}=0.00902$ ).

Proconvertin (coagulation factor FVII) participates in the external mechanism of blood coagulation. Thrombin catalyzes conversion of fibrinogen to fibrin and formation of clot, arresting bleeding. In case of hypoproconvertinemia formation of thrombin becomes slow and hemorrhagic complications develop. Frequency of AG variant of $F 7$ 353GIn (G10976A) polymorphism in European population comprises $10-20 \%$, but until present its influence on chorion detachment has not been determined.

MTRR gene is known to encode amino acid sequence of methionine synthase reductase, one of the function of which is reconversion of homocysteine into methionine. As a result of replacement of amino acid residue, isoleucine, by methionine in position 66 functional activity of the enzyme decreases, the processes of DNA methylation impair. DNA methylation plays a leading role in the formation and maintaining of epigenetic variability - an inherited dynamic process, determining the degree of gene activity. The elicited fact allows to advance the following hypothesis: the deficiency of methionine synthase reductase enzyme is accompanied by the shortage of methyl groups, which, in its turn, affects the epigenetic status and realization of hypoconvertinemia, caused by mutation of coagulation factor $F 7$, resulting finally in chorion detachment.

There was no relation between chorion detachment and presence of low-functional alleles of MTHFR 667T genotype found within the framework of the given study due to the absence of statistical significance of the obtained index according to the Hardy-Weinberg equilibrium test.

Conclusion. Chorion detachment in women being in the first trimester of pregnancy may be the result of the availability of heterozygous variant of F7 (proconvertin, FVII) G10976A polymorphism and mutant homozygous GG variant of MTRR A66G polymorphism, that can occur both separately and in combination. If these polymorphisms together with deficiency of methyl groups are present, hypoconvertinemia is the cause of hemostatic 'lock' failure, resulting in the formation of retrochorial hematoma.

Study Funding and Conflicts of Interest. This study was funded by the authors. There is no topic specific conflict of interest related to the authors of this study.

\section{References}

1. Nagy S., Bush M., Stone J., Lapinski R., Gardó S. Clinical significance of subchorionic and retroplacental hematomas detected in the first trimester of pregnancy. Orv Hetil 2005 Oct; 146(42): 2157-2161.

2. Tuuli M.G., Norman S.M., Odibo A.O., Macones G.A., Cahill A.G. Perinatal outcomes in women with subchorionic hematoma: a systematic review and meta-analysis. Obstet Gynecol 2011 May; 117(5): 1205-1212, http://dx.doi. org/10.1097/AOG.0b013e31821568de.

3. Vaginal bleeding during pregnancy. In: Ferri's clinical advisor. Editor by Fred F. Ferri. Mosby; 2014; p. 1143-1143.

4. Kyser Kathy L. Meta-analysis of subchorionic hemorrhage and adverse pregnancy outcomes. Proc Obstet Gynecol 2012; 2(4), URL: http://ir.uiowa.edu/cgi/viewcontent.cgi?article=1137\& context=pog.

5. Sidel'nikova V.M., Sukhikh G.T. Nevynashivanie beremennosti [Miscarriage]. Moscow: 000 "Meditsinskoe informatsionnoe agentstvo"; 2010; $536 \mathrm{p}$.

6. Makatsariya A.D. Trombogemorragicheskie oslozhneniya $v$ akushersko-ginekologicheskoy praktike [Thrombohemorrhagic complications in obstetric-gynecologic practice]. Moscow: MIA; 2011.

7. Kupferminc M.J. Thrombophilia and pregnancy. Curr Pharm Des 2005; 11(6): 735-748, http://dx.doi.org/10.2174/13 81612053381855.

8. Procházka M., Happach C., Marsál K., Dahlbäck B., Lindqvist P.G. Factor $V$ Leiden in pregnancies complicated by placental abruption. BJOG 2003 May; 110(5): 462-466, http:// dx.doi.org/10.1046/j.1471-0528.2003.02369.x.

9. Rodger M.A., Betancourt M.T., Clark P., Lindqvist P.G., Dizon-Townson D., Said J., Seligsohn U., Carrier M., Salomon O., Greer I.A. The association of factor V Leiden and prothrombin gene mutation and placenta-mediated pregnancy complications: a systematic review and meta-analysis of prospective cohort studies. PLoS Med 2010 Jun; 7(6): e1000292, http://dx.doi. org/10.1371/journal.pmed.1000292.

10. Said J.M., Higgins J.R., Moses E.K., Walker S.P., Borg A.J., Monagle P.T., Brennecke S.P. Inherited thrombophilia polymorphisms and pregnancy outcomes in nulliparous women. Obstet Gynecol 2010 Jan; 115(1): 5-13, http://dx.doi. org/10.1097/AOG.0b013e3181c68907.

11. Akin'shina S.V., Smirnova L.M., Makatsariya A.D. Vedenie beremennosti i rodov $u$ patsientok $s$ trombozami i tromboemboliyami $\mathrm{v}$ anamneze. $\mathrm{V}$ kn.: Sovremennaya perinatologiya: organizatsiya, tekhnologii $i$ kachestvo [Pregnancy and labor management in patients with thrombosis and thromboembolism in the history. In: Modern perinatology: organization, technologies and quality]. Moscow; 2010; p. 4.

12. Tetruashvili N.K., Agadzhanova A.A., Ionanidze T.B. Hemostatic therapy in hemorrhages during pregnancy Effektivnaya farmakoterapiya. Akusherstvo i ginekologiya 2013; 1: 6-10.

13. VettriselviV., VijayalakshmiK., PaulS.F., Venkatachalam P. ACE and MTHFR gene polymorphisms in unexplained recurrent pregnancy loss. J Obstet Gynaecol Res 2008; 34(3): 301-306, http://dx.doi.org/10.1111/j.1447-0756.2008.00792.x.

14. Beskorovainaia T.S., Gudzenko S.V., Tverskaia S.M., Poliakov A.V. The association of polymorphic alleles of folate 


\section{CLIVICAL MEDICINE}

metabolism genes with recurrent pregnancy loss. Problemy reproduktsii 2006; 1: 53-60.

15. Geneticheskiy pasport - osnova individual'noy $i$ prediktivnoy meditsiny [Genetic passport is the basis of personalized and predictive medicine]. Pod. red. Baranova V.S. [Baranov V.S. (editor)]. Saint Petersburg: Izd-vo N-L; 2009; $528 \mathrm{p}$.

16. Kiryushchenkov P.A., Shmakov R.G., Andamova E.V.,
Tambovtseva M.A. An algorithm for clinical and hemostasiological investigation in obstetric and gynecological care. Akusherstvo $i$ ginekologiya 2013; 1: 101-106.

17. Akinshina S.V., Bitsadze V.O., Baimuradova S.M., Makatsaria A.D. P.82 Prevention of recurrent thromboembolic complications in women with thrombophilia. Thrombosis Research 2011 Feb; 127(Suppl 3): S148, http://dx.doi. org/10.1016/s0049-3848(11)70137-2. 